\title{
ARQUIVOS
}

\section{INVENTÁRIO DE DOCUMENTOS INÉDITOS DE INTERESSE PARA A HISTÓRIA DE SÃO PAULO (IV)}

(Biblioteca Nacional de Lisboa - Fundo Geral)

(Conclusāo)

B.N.L.

F.G. 238

(Carta de D. João V ao governador e capitão general da Capitania de S. Paulo, informando-o ter perdoado aos moradores da Vila de Goratinguetá, o resto que deviam da contribuição para os casamentos dos Principes do Brasil).

1743. Março, 16 - Lisboa.

Cópia. Letra do séc. XIX. A fl. 202 v.

B.N.L.

F.G. 238

(Carta de D. João $\mathrm{V}$ ao governador e capitão general da Capitania de S. Paulo, sôbre a informação que lhe deu o Juiz de Fora que foi da Vila de Santos, Gaspar da Rocha Pereira, sôbre as negociações e descaminhos operados pelo Governador da Praça de Santos, o Provedor da Fazenda e o Almoxarife dela, Bento do Crasto Carneiro, contra a Real Fazenda; pelo que lhe pede um parecer, e lhe ordena que logo que finde o tempo do Almoxarife da Vila de Santos, a Cámara proponha outros para servir o dito cargo).

1743. Março, 7 - Lisboa.

Cópia. Letra do séc. XIX, a fl. 202 v.

B.N.L.

F.G. 238

(Carta de D. João V ao governador e capitão general da Capitania de S. Paulo, ordenando-lhe que dê execução ao Decreto de 14 de março de 1743 , em que se determina que se conservem e reponham os oficios no estado em que se acharam quando se arrendaram por donativos).

1743. Março, $23 \sim$ Lisboa.

Cópia. Letra do séc. XIX. A fl. 203.

B.N.L.

F.G. 238

(Carta de D. João V ao governador e capitão general da Capitania de $\mathrm{S}$. Paulo, ordenando-the que declare o número de religiosos com que foram estabelecidas as Religiōes da Capitania, e os que entende que lhe possam ser precisos presentemente).

1743. Março, 18 - Lisboa.

Cópia. Letra do séc. XIX. A fl. 203. 
B.N.L.

F.G. 238

(Carta de D. João V ao governador e capitão general da Capitania de S. Paulo, informando-o que por resolução sua de 6 de março de 1743, lhe ordena que faça ir para a Ilha de Santa $\mathrm{Ca}$ tarina a aldeia de Indios de S. João de Tanhanhen, a pedido do Brigadeiro José da Silva Paes).

1743. Março, 26 - Lisboa.

Cópia. Letra do séc. XIX. A fl. 203 v.

B.N.L.

F.G. 238

(Carta de D. João $\mathrm{V}$ ao governador e capitão general da Capitania de S. Paulo, pedindo-lhe que informe a respeito do requerimento que lhe fêz o Tenente General da Capitania de S. Paulo, Manuel Rodrigues de Carvalho, em que pede a S.M. que the mande satisfazer pela Real Fazenda, os gastos que fêz na guerra feita ao gentio Payaguaz).

1743. Março, 29 - Lisboa.

Cópia. Letra do séc. XIX. A fl. 203 v.

B.N.L.

F.G. 238

(Carta de D. João $\mathrm{V}$ ao governador e capitão general da Capitania de S. Paulo, informando-o que concedeu a Antônio da Silveira Mota, Ajudante de Tenente em S. Paulo, licença para ir ao Reino tratar de sua saude, e das suas dependências).

1743. Abril, 3 - Lisboa.

Cópia. Letra do séc. XIX. A fl. 204.

B.N.L.

F.G. 238

(Carta de D. João V ao governador e capitão general da Capitania de $S$. Paulo, pedindo-lhe um parecer sôbre a preferência que tem o Reitor do colégio da cidade de S. Paulo, Padre Belchior Mendes, querendo que estejam as suas embarcaçōes nos portos de Santos e Cubatão).

1745. Abril, 4 - Lisboa.

Cópia. Letra do séc. XIX. A fl. 204 v.

Outra igual de 7 de Setembro de 1745, a fl. 216.

B.N.L.

F.G. 238

(Carta de $\mathrm{D}$. João $\mathrm{V}$ ao governador e capitão general da Capitania de S. Paulo, ordenando-lhe que faça publicar no distrito do seu Govêrno a Lei sóbre a propinação do veneno).

1743. Abril, 4 - Lisboa.

Cópia. Letra do séc. XIX. A fl. 204 v.

B.N.L.

F.G. 238

(Carta de $\mathrm{D}$. João $\mathrm{V}$ ao governador e capitão general da Capitania de S. Paulo, ordenando-lhe que se entreguem a Vicente Dias de Carvalho, que foi contratador dos dizimos reais das Minas de Goiaz, o produto dos dizimos dos novos descobertos, na forma das condiçóes $20^{A}$ e $100^{\wedge}$ do seu contrato).

1743. Junho, 7 - Lisboa.

Cópia. Letra do séc. XIX. A fl. 205. 
B.N.L.

F:G. 238

(Carta de D. João $\mathrm{V}$ ao governador e capitão general da Capitania de S. Paulo, ordenando-lhe que mande demolir as engenhocas de fazer água-ardente, logo que finde o contrato dos dízimos das Minas de Goiaz e Cuiabá, e que proiba a sua reedificação sob pena de 2.000 cruzados de multa).

1743. Junho, 12 - Lisboa.

Cópia. Letra do séc. XIX. A fl. 205 v.

B.N.L.

F.G. 238

(Carta de $\mathrm{D}$. João $\mathrm{V}$ ao governador e capitão general da Capitania de S. Paulo, informando-o que por resolução de 12 de junho de 1743, aprovou a divisão que fêz Gomes Freire de Andrade, do govêrno de Minas Gerais do de S. Paulo, pela parte das Minas de Goiaz).

1743. Junho, $22-$ Lisboa.

Cópia. Letra do séc. XIX. A fl. 206.

B.N.L.

F.G. 238

(Carta de D. João $V$ ao governador e capitão general da Capitania de S. Paulo, informando-o que determinou que as sesmarias que se derem nas terras onde haja minas ou nos caminhos para minas, sejam só de meia légua em quadro, e que no mais sertão sejam de 3 léguas, e que para as sesmarias se concederem sejam ouvidas também as Câmaras dos sitios a que elas pertençam). 1744. Abril, 15 - Lisboa.

Cópia. Letra do séc. XIX. A fl. 206 v.

B.N.L.

F.G. 238

(Carta de $\mathrm{D}$. João $\mathrm{V}$ ao governador e capitão general da Capitania de S. Paulo, informando-o que escusou o requerimento de Manuel da Cunha Castelo Branco a respeito do acôrdo que tinha feito com a Cámara da Vila de Ibatuba para abrir caminho de outras vilas para aquela).

1743. Setembro, 14 - Lisboa.

Cópia. Letra do séc. XIX. A fl. 206 v.

B.N.L.

F.G. 238

(Carta de D. João V ao governador e capitão general da Capita. nia de Estado das Minas da Cidade de S. Paulo, mandando fazer a execução nos bens de Manuel Antunes de Andrade pelo que êle é devedor à Fazenda Real do tempo que foi executor do Almoxarifado da Vila de Abrantes). 1744. Abril, 20 - Lisboa.

Cópia. Letra do séc. XIX. A fl. 207.

B.N.L.

F.G. 238

(Carta de D. João V a D. Luiz de Mascarenhas, governador e capitão general da capitania de S. Paulo, pedindo conta do descobrimento a que foi João Bicudo de Brito e da ordem por que lhe fêz o empréstimo, da Fazenda Real).

1744. Abril, 30 - Lisboa.

Cópia. Letra do Séc. XIX. A fl. 207 v. 
B.N.L.

F.G. 238

(Carta de D. João V a D. Luiz de Mascarénhas, governador e capitão general da capitania de S. Paulo, pedindo-lhe informação do descobrimento a que foi João Bicudo de Brito, e porque razão lhe fêz um empréstimo da Real Fazenda).

1744. Abril, $30-$ Lisboa.

Cópia. Letra do séc. XIX. A fl. 207 v.

B.N.L.

F.G. 238

(Carta de D. João V ao governador e capitão general da capitania de S. Paulo, pedindo informação a respeito do aumento de ordenado pedido pelo Juiz de Fora da Praça de Santos).

1744. Abril, 23 - Lisboa.

- Cópia. Letra do sêc. XIX. A fl. 207 v.

B.N.L.

F.G. 238

(Carta de D. João V ao governador e capitão general da Capitania de S. Paulo, dando-lhe parte da sua resolução no que diz respeito aos gastos que os Ouvidores mandam fazer aos Oficiais da Câmara).

1744. Maio, 12 - Lisboa.

Cópia. Letra do séc. XIX. A fl. 208.

B.N.L.

F.G. 238

(Carta de D. João V a D. Luiz Mascarenhas, governador e capitão general da Capitania de S. Paulo, louvando a sua ação em ter dado conta de várias matérias).

1744. Maio, 5 - Lisboa.

Cópia. Letra do séc. XIX. A fl. 208 v.

B.N.L.

F.G. 238

(Carta de D. João $\mathrm{V}$ ao governador e capitão general da Capi-. tania de S. Paulo, pedindo informação dos contratos que devem ficar na Provedoria de Santos para êste poder suprir as despesas a que é obrigada).

1744. Maio, 5 - Lisboa.

Cópia. Letra do séc. XIX. A fl. 208 v.

B.N.L.

F.G. 238

(Carta de D. João $\mathrm{V}$ ao governador e capitão general da Capitania de S. Paulo, acusando recepção de 123.448 oitavas de ouro em pó pelo tesoureiro do Conselho Ultramarino).

1744. Maio, $6-$ Lisboa.

Cópia. Letra do séc. XIX. A fl. 209.

B.N.L.

F.G. 238

(Carta de D. João V a D. Luiz de Mascarenhas, governador e capitão general da Capitania de S. Paulo, pedindo para se informar de todos os opositores a que seja promovido para o posto de ajudante de tenente, Antônio Francisco Barris, capitão de Infantaria).

1744. Maio, 11 - Lisboa.

Cópia. Letra do séc. XIX. A fl. 209. 
B.N.L.

F.G. 238

(Carta de D. João V ao governador e capitão general da Capitania de $\mathrm{S}$. Paulo, pedindo informação a respeito do Intendente Bartolomeu Correia Bueno, que foi para as Minas do ouro do Rio Verde).

1744. Maio, 12 - Lisboa.

Cópia. Letra do séc. XIX. A fl. 209 v.

B.N.L.

F.G. 238

(Carta de D. João V ao governador e capitão general da Capitania de S. Paulo, pedindo um parecer sôbre o requerimento feito pelos Alferes da Guarnição da Praça de Santos para o seu soldo ser igualado ao dos alferes da Praça do Rio de Janeiro).

1744. Maio, 15 - Lisboa.

Cópia. Letra do séc. XIX. A fl. 209 v.

B.N.L.

F.G. 238

(Carta de $\mathrm{D}$. João $\mathrm{V}$ ao governador e capitão general da Capitania de S. Paulo, pedindo um parecer sôbre o requerimento feito pelo sargento mor Torcato Teixeira de Carvalho, no qual pede por mais vidas a mercê feita a seu filho Joaquim Teixeira de Carvalho),

1744. Maio, $21-$ Lisboa.

Cópia. Letra do séc. XIX. A fl. 210.

B.N.L.

F.G. 238

(Carta de D. João V a D. Luiz de Mascarenhas, governador e capitão general da Capitania de S. Paulo, aprovando a guerra feita ao gentio do Coiso que tem feito mortes, roubos e outras hostilidades aos moradores de Vila Boa de Goiaz, recomendando porém que procure não fazer guerra se isso fôr possivel).

1744. Maio, 23 - Lisboa.

Cópia. Letra do séc. XIX. A fl. 210.

B.N.L.

F.G. 238

(Carta de D. João V ao governador e capitão general da Capi- , tania de S. Paulo, dando ordem para que sejam ouvidas as Câmaras a respeito da confinação de sesmarias que the é perdida por várias pessoas).

1744. Maio, 25 - Lisboa.

Cópia. Letra do séc. XIX. A fl. 210 v.

B.N.L.

F.G. 238

(Carta de D. João $\mathrm{V}$ ao governador e capitão general da Capitania de S. Paulo, informando-o que João Francisco rematou o contrato do subsidio dos molhados e novo impôsto da Praça de Santos, por 3 anos, pelo que lhe ordena que faça cumprir as condições impostas no dito contrato).

1744. Maio, 28 - Lisboa.

Cópia. Letra do séc. XIX. A fl. 211. 
B.N.L.

F.G. 238

(Carta de D. João V ao" governador e capitão general da Capitania de S. Paulo, pedindo-lhe um parecer sôbre o pedido que lhe fêz João Abreu, o qual pretendia ter no posto de Sargento mor da Praça de Santos o mesmo soldo que tinha no posto de Capitão de Infantaria; e pedindo-lhe também S.M. uma declaração das criações e obrigações atuais dêste posto).

1744. Setembro, 17 - Lisboa.

Cópia. Letra do séc. XIX. A fl. 211.

B.N.L.

F.G. 238

(Carta de D. João V ao governador e capitão general da Capitania de S. Paulo, informando-o que Francisco da Silva Lisboa, rematou o contrato das passagens antigas de Santos e de S. Paulo, por 3 anos; pelo que lhe pede que faça cumprir o dito contrato e suas condiçōes).

1744. Maio, 27 - Lisboa.

Cópia. Letra do séc. XIX. A fl. 211.

B.N.L.

F.G. 238

(Carta de $\mathrm{D}$. João $\mathrm{V}$ ao governador e capitão general da Capitania de S. Paulo, enviando-lhe a cópia da ordem que mandou expedir ao Provedor mor da Fazenda Real do Estado do Brasil, para que se aceitem as baixas que os comandantes dos Terços e Companhias mandem dar aos soldados ausentes, ordem esta que S.M. manda registar na Provedoria do Govêrno de S. Paulo, para que ai se observe).

1744. Setembro, 19 - Lisboa.

Cópia. Letra do séc. XIX. A fl. 211 v.

B.N.L.

F.G. 238

(Carta de $\mathrm{D}$. João $\mathrm{V}$ ao governador e capitão general da Capitania de S. Paulo, informando-o que resolveu que se observem na capitania as ordens do contador mor do Reino, respeitantes a contas).

1744. Novembro, 19 - Lisboa.

B.N.L.

F.G. 238

Cópia. Letra do séc. XIX. A fl. 211 v.

(Carta de D. João V'ao governador e capitão general da Càpitania de S. Paulo, pedindo-lhe um parecer sôbre o pedido que lhe fizeram os oficiais da Câmara de Parnaguá para que mandasse entregar aos religiosos de $\mathrm{S}$. Francisco uma capela erigida por José da Silva Barros para os mesmos frades).

1745. Abril, 1 - Lisboa.

B.N.亡.

Cópia. Letra do séc. XIX. A fl. 212.

F.G. 238

(Carta de D. João V ao governador e capitão general da Capitania de S. Paulo, pedindo um parecer sôbre o requerimento do Bacharel Luiz de Campos, em que pede a confirmação do cargo de Procurador da Coróa com a metade do ordenado que se paga ao do Rio de Janeiro).

1745. Abril - Lisboa.

Cópia. Letra do séc. XIX. A fl. 212. 
B.N.L.

F.G. 238

(Carta de D. João V ao governador e capitão general da Capitania de S. Paulo, informando-o de que se escusou a patente que se passou a Alexandre Monteiro de Sampaio, do posto de Mestre de Campo das Ordenanças de Uubatuba, por estas deverem de ser governadas por capitães mores).

1745. Abril, 13 - Lisboa.

Cópia. Letra do séc. XIX. A fl. 212.

B.N.L. F.G. 238

(Carta de $\mathrm{D}$. João $\mathrm{V}$ ao governador e capitão general da Capitania de S. Paulo, dizendo-lhe que ordene ao Ouvidor, que como auditor da gente de guerra, autui o alferes Luiz Pimentel de Sousa por ter intimado com ordem falsa que só se auxiliassem as justiças contra facinorosos; e se mande advertir aos cabos que assistirem nos destacamentos, não faltem em auxiliar as diligências do seu Real Serviço).

1745. Abril, 5 - Lisboa.

Cópia. Letra do séc. XIX. A fl. 212 v.

B.N.L.

F.G. 238

(Carta de D. João V ao governador e capitão general da Capitania de S. Paulo, pedindo um parecer sôbre a carta enviada a S.M. por Gomes Freire de Andrade, governador e capitão general do Rio de Janeiro, $є m$ que êste se refere ao rendimento do direito imposto nas cavalgaduras vindas do Rio Grande de $\mathbf{S}$. Pedro).

1745. Abril, 7 - Lisboa.

- Cópia. Letra do séc. XIX. A fl. 212 v.

B.N.L.

F.G. 238

(Carta de D. João V ao governador e capitão general da Capitania de S. Paulo, pedindo um parecer sôbre a representação que fizeram os oficiais da Câmara de Vila de Parnaguá, a respeito de se obrigarem as embarcaçōes que carregam naquele pôrto para - Rio de Janeiro, a irem primeiro ao Pôrto de Santos, e o prejuizo que dai advem).

1745. Abril, 8 - Lisboa.

Cópia. Letra do séc. XIX. A fl. 212 v.

B.N.L.

F.G. 238

(Carta de D. João $V$ ao governador e capitão general da Capitania de S. Paulo, pedindo um parecer sôbre a representação que fizeram os oficiais da Câmara da Vila do Sabará, para se tirarem 200 casais de Tapuyis da Capitania para as Minas, para dali sairem a destruir os quilombos aos negros que roubam e matam viandartes).

1745. Abril, 9 - Lisboa.

Cópia. Letra do séc. XIX. A fll. 213.

B.N.L.

F.G. 238

(Carta de D. João V ao governador e capitão general da Capitania de S. Paulo, pedindo um parecer sôbre a representação do 
Ouvidor Geral dessa Comarca, acêrca de ser justo declarar que deve levar propina das festas reais a que não assistirem os Ouvidores, achando-se em correição).

17.45. Abril, 9 - Lisboa.

Cópia. Letra do séc. XIX. A fl. 213.

B.N.L.

F.G. 238

(Carta de D. João $\mathrm{V}$ ao governador e capitão general da Capitania de S. Paulo, pedindo-lhe informação sôbre o requerimento de Manuel Mendes Cardoso, cuja cópia the envia, o qual pede para the ser passada carta do cargo de cirurgião-mor da Praça de Santos).

1745. Abril, 12 - Lisboa.

Cópia. Letra do séc. XIX. A fl. 213 v.

B.N.L.

F.G. 238

(Carta de D. João $\mathrm{V}$ ao governador e capitão general da Capitania de S. Paulo, pedindo-lhe um parecer sôbre o pedido dos Oficiais da Camara da Cidade de $\mathrm{S}$. Paulo os quais pedem que sejam aquéles moradores aliviados de aquartelar os soldados de cavalo que vão buscar os Reais Quintos das Minas do Goiaz; e sejam os mesmos soldados assistidos pela Real Fazenda).

1745. Abril, 10 - Lisboa.

Cópia. Letra do séc. XIX. A fl. 213 v.

B.N.L.

F.G. 238

(Carta enviada por Manuel Caetano Lopes do Lavre, a D. Luiz Mascarenhas, remetendo as leis sóbre a arqueaçáo que se deve fazer nos navios que vão carregar escravos, para que éle a faça observar na Praça de Santos).

1745. Abril, 23 - Lisboa.

Cópia. Letra do séc. XIX. A fl. 214.

B.N.L.

F.G. 238

(Carta de D. João $\mathrm{V}$ ao governador e capitão general da Capitania de S. Paulo, pedindo um parecer sôbre o requerimento de Francisco Fernandes Montanha, que pede para vencer o seu soldo por inteiro).

1745. Abril, 20 - Lisboa.

Cópia. Letra do séc. XIX. A fl. 214.

B.N.亡.

F.G. 238

(Carta de $\mathrm{D}$. João $\mathrm{V}$ ao governador e capitão general da capitania de S. Paulo. pedindo-lhe um parecer sôbre a representação dos oficiais da Câmara da Vila de Goratinguetá, que pedem que naquela Vila se erija um Hospicio Franciscano).

1745. Abril, 22 - Lisboa.

Cópia. Letra do séc. XIX. A fl. 214.

B.N.L.

F.G. 238

(Carta de $D$. João $V$ ao governador e capitão general da Capitania de S. Paulo, informando-o que resolveu que se dê de soldo 
a cada um dos Alferes de Infantaria da Praça de Santos, 9.600 réis por mês).

1745. Abril, 24 - Lisboa.

Cópia. Letra do séc. XIX. A fl. 214 v.

B.N.L.

F.G. 238

B.N.L.

F.G. 238

(Carta de Antônio Guedes Pereira a D. Luiz de Mascarenhas, acusando a recepção das listas das avaliaçōes dos ofícios daquela capitania de S. Paulo e Minas dos Goiazes, e a lista dos donativos que pagam; e dizendo-lhe que S.M. mandou fazer nova avaliação dos oficios da capitania de S. Paulo).

1745. Abril, 27 - Lisboa.

Cópia. Letra do séc. XIX. A fl. 215.

B.N.L

F.G. 238

(Carta de D. João V ao governador e capitão general da Capitania de S. Paulo, dizendo-lhe que manda remeter soldados para a guarnição da fortaleza da liha de S. Catarina e do Rio de S. Pedro, e, em cada navio que vá das ilhas para os portos do Brasil se mandem 5 casais para os presidios da Ilha de $\mathrm{S}$. Catarina e do Rio de S. Pedro).

1745. Abril, 27 - Lisboa.

Cópia. Letra do séc. XIX. A fl. 215.

B.N.L

F.G. 238

(Carta de Manuel Caetano Lopes do Lavre, a D. Luiz de Mascarenhas, informando-o que S.M. ordena que os governadores das conquistas o informem àcêrca dos rendimentos dos donatários).

1745. Abril, 27 - Lisboa.

Cópia. Letra do séc. XIX. A fl. 215.

B.N.L.

F.G. 238

(Carta de D. João V ao governador e capitão general da Capitania de $\mathrm{S}$. Paulo, pedindo-lhe um parecer sôbre a petição dos ajudantes supra e do número de Infantaria da guarnição da Praça de Santos, que pedem para serem igualados os soldos aos dos Ajudantes do Rio de Janeiro).

1745. Agôsto, 28 - Lisboa.

Cópia. Letra do séc. XIX. A fl. 215 v.

B.N.L.

F.G. 238

(Carta de D. João V ao governador e capitão general da Capitania de S. Paulo, pedindo-lhe um parecer sôbre o pedido de aumento de ordenado que fêz a S.M. Miguel das Águias Carneiro, escrivão da Alfândega e Matricula da Praça de Santos).

1745. Abril, 29 - Lisboa.

Cópia. Letra do séc. XIX. A fl. 215 v. 
B.N.E.

F.G. 238

B.N.L

F.G. 238

(Carta de D. João V ao governador e capitão general da Capi- . tania de $S$. Paulo, determinando o que devem vencer os soldos os Ajudantes pagos e os Ajudantes supra dos auxiliares, e dizendo-lhe que quando vagar alguma bengala de ajudante de Auxiliares proponha o Coronel 3 pessoas para que seja uma eleita). 1745. Outubro, 29 - Lisboa.

Cópia. Letra do séc: XIX. A fl. 216 v.

B.N.L.

F.G. 238

(Carta enviada por Pedro da Mota e Silva ao governador e capitão general da Capitania de S. Paulo, informando-o que S.M. resolveu que o Bispo de $S$. Paulo e seus sucessores, em tôda a parte e lugar precedam sempre aos governadores e outras pessoas de destaque, e sejam tratados com as devidas reverências). 1746. Abril, 18 - Lisboa.

Cópia. Letra do séc. XIX. A fl. 217.

B.N.L.

P.G. 238

(Carta de D. João V a D. Luiz de Mascarenhas, governador e capitão general da Capitania de S. Paulo, ordenando-lhe que restitua ao posto de Intendente e Superintendente das Minas de Paranampanema, Antônio Pissaro, e ao de Tesoureiro da Intendência da Câmara de Parnágua, Luiz da Rocha Martins).

1746. Maio, 24 - Lisboa.

Cópia. Letra do séc. XIX. A fl. 217.

B.N.L.

F.G. 238

(Carta de D. João $\mathrm{V}$ ao governador e capitão general da Capitania de S. Paulo, pedindo um parecer sôbre se os capitães mores das Ordenanças devem ser nomeados trienal ou vitaliciamente).

1746. Maio, 22 - Lisboa.

Cópia. Letra do séc. XIX. A fl. 217.

B.V.L.

F.G. 238

(Carta de D. João V a D. Luiz de Mascarenhas, governador e capitão general da Capitania de S. Paulo, participando o nascimento de sua neta, e dizendo-lhe que festeje o acontecimento com as demonstrações militares da praxe).

1746. Julho, 25 - Lisboa.

Cópia:-Letra do séc. XIX. A fl. 217 v. 
B.N.L.

F.G. 238

(Carta de D. João V a D. Luiz de Mascarenhas, governador e capitão general da Capitania de S. Paulo, sôbre o procedimento de José de Barros Lima, quanto à divisão das terras das Minas de S. José dos Pinhais, de que é guarda-mor, o qual não atendeu ao Indio que as descobriu, e ficou com a melhor parte; pelo que lhe pede um parecer sôbre ter confirmado aquela divisão em prejuizo da Real Fazenda).

1746. Maio, 24 - Lisboa.

Cópia. Letra do séc. XIX. A fl. 217 v.

B.N.L.

F.G. 238

(Carta de D. João V ao governador e capitão general da Capitania de S. Paulo, aprovando o seu procedimento quanto à queixa apresentada pelos moradores de Mogi-Guassú contra o vigário da Vara de S. Paulo, Manuel da Costa Abranches).

1746. Setembro, 13 - Lisboa.

Cópia. Letra do séc. XIX. A fl. 218.

B.N.L.

F.G. 238

(Carta enviada por Pedro da Mota e Silva ao governador e capitão general da Capitania de S. Paulo, dizendo-lhe que S.M. the manda dizer que obrigue os povos da capitania a ajoelhar-se quando passar o bispo pela rua, e as igrejas ou religiōes repiquem sempre que o bispo passar à vista delas).

1746. Abril, 18 - Lisboa.

Cópia. Letra do séc. XIX. A fl. 218 v.

B.N.L.

F.G. 238

(Carta de D. João $\mathrm{V}$ ao governador e capitão general da Capitania de S. Paulo, ordenando-lhe que faça observar inteiramente a condição 3.* do Contrato das Entradas das Minas, rematado por Jorge Pinto de Azevedo).

1746. Abril, 26 - Lisboa.

Cópia. Letra do sêc. XIX. A fl. 218 v.

B.N.L.

F.G. 238

(Carta de D. João $\mathrm{V}$ ao governador e capitão general da Capitania de S. Paulo, ordenando-lhe que dê ao novo Bispo de $S$. Paulo, a ajuda e favor de que necessitar para a criação dêste Bispado, e para tudo o que fốr exercitar o seu Pastoral Ofício). 1746. Abril, 18 - Lisboa.

Cópia. Letra do séc. XIX. A fl. 218 v.

B.N.L.

R.G. 238 .

(Carta de D. João V ao governador e capitão general da Capitania de S. Paulo, ordenando-lhe que deve mandar passar as $\mathrm{Pa}$ tentes das Ordenanças em conformidade com as Ordens de 23 de Fevereiro de 1733 e de 2 de Dezembro de 1744). 1746. Abril, 27 - Lisboa.

Cópia. Letra do séc. XIX. A fl. 219. 
B.N.L.

F.G. 238

(Carta de D. João $\mathrm{V}$ ao governador e capitão general da Capitania de S. Paulo, informando-o que mandou remeter as balas emunições que constavam na lista por êle enviada; e que êle deve mandar, além da lista das munições que se achiam no Trem da. Praça de Santos, a lista das que são precisas para a defesa da. mesma).

1746. Abril, 28 - Lisboa.

Cópia. Letra do séc. XIX. A fl. 219.

B.N.L.

F.G. 238

(Carta de D. João V ao governador e capitão general da Capitania de S. Paulo, dizendo-lhe que na sua jurisdição não cabe. proibir os vassalos de S.M. a liberdade de navegar e comerciar nos portos que não são vedados por S.M.).

1746. Abril, 28 - Lisboa.

Cópia. Letra do séc. XIX. A fl. 219 v.

B.N.L.

F.G. 238

(Carta de D. João V a D. Luiz de Mascarenhas, governador e capitão general da Capitania de S. Paulo, dizendo-lhe que continui a adotar os meios mais convenientes para evitar os danos. ocasionados pelos quilombos, e pedindo-lhe um parecer sóbre a falta de água que têm os mineiros do Cuiabá).

1746. Abril, 29. - Lisboa.

Cópia. Letra do séc. XIX. A fl. 220.

B.N.L.

F.G. 238

(Carta de $\mathrm{D}$. João $\mathrm{V}$ ao governador e capitão general da Capitania de S. Paulo, dizendo-lhe que não consinta que os soldados, que conduzem os Reais Quintos das Minas dos Goiazes para S: Paulo, façam opressão aos paisanos nem exijam mais do que o que êles são obrigados a dar-lhes e que lhes determine o tempo que êles podem estar naquela cidade).

1746. Maio, 4 - Lisboa.

Cópia. Letra do séc. XIX. A fl. 220 v.

B.N.L.

F.G. 238

(Carta de D. João V ao governador e capitão general da Capitania de $\mathrm{S}$. Paulo, pedindo um parecer sôbre a representação que lhe fizeram os oficiais da Câmara daquela cidade, dizendo que seria conveniente criar-se uma companhia de dragōes).

1746. Maio, 4 - Lisboa.

Cópia. Letra do séc. XIX: A-fl. 220 v.

B.N.L.

F.G. 238

(Carta de D. João V ao governador e capitão general da Capitania de S. Paulo, pedindo um parecer sôbre o oferecimento que fêz o mestre de campo João de Távora, para edificar na Vila de Parnaguá um forte, concedendo-lhe S.M. o contido nas condiçōes que junto lhe enviou).

1746. Maio, 4 - Lisboa.

Cópia. Letra do séc. XIX. A fl. 221. 
B.N.L. F.G. 238

(Carta de D. João V ao governador e capitão general da Capitania de S. Paulo, sôbre a quantia com que devem contribuir as Câmaras para as devassas que se tirarem em certos casos).

1746. Maio, 5 - Lisboa.

Cópia. Letra do séc. XIX. A fl. 221.

B.N.L. F.G. 238

(Carta de D. João V ao governador e capitão general da Capitania de S. Paulo, dizendo-lhe que deve dar ajuda militar para as diligências criminais da Fazenda Real, e nas mais que forem do serviço de S.M.).

1746. Maio, 5 - Lisboa.

Cópia. Letra do séc. XIX. A fl. 221 v.

B.N.L.

F.G. 238

(Carta de D. João V ao governador e capitão general da Capitania de $\mathbf{S}$. Paulo, pedindo um parecer sôbre o pedido que the fêz Francisco de Almeida Albernas, para saber se é capitão mais antigo do que Manuel Martins dos Santos).

1746. Maio, 5 - Lisboa.

Cópia. Letra do séc. XIX. A fl. 221 v.

B.N.L.

F.G. 238

(Carta de D. João V ao governador e capitão general da Capitania de S. Paulo, informando-o de que determinou, por resolução de 2 de maio de 1746, que se criem na Vila de Parnaguá, 2 tabeliães do judicial e notas, um juiz e um escrivão dos órfãos).

1746. Maio, 5 - Lisboa.

Cópia. Letra do séc. XIX. A fl. 221 v.

B.N.L.

F.G. 238

B.N.L.

F.G. 238

(Carta de D. João $\mathrm{V}$ ao governador e capitão general da Capitania de S. Paulo, informando-o que determinou por Decreto de 5 de maio de 1741, que os ofícios e mais funções da igreja paroquial de S. Paulo, se exercitem na Igreja da Misericórdia, enquanto aquela estiver em obras).

1746. Maio, 6 - Lisboa.

Cópia. Letra do séc. XIX. A fl. 222.

(Carta de D. João V ao governador e capitão general da- capitania de $\mathrm{S}$. Paulo, ordenando-lhe que determine o sitio para a nova Catedral de S. Paulo, e para o Palácio Episcopal). 1746. Maio, 6 - Lisboa.

B.N.L.

Cópia. Letra do séc. XIX. A fl. 222 v.

F.G. 238

(Carta de D. João $\mathrm{V}$ ao governador e capitão general da Capitania de S. Paulo, pedindo-lhe um parecer sôbre o modo "de se consertarem os caminhos que vão de $\mathrm{S}$. Paulo para várias parteś; os quais se encontram por vêzes intransitáveis).

1746. Maio, 6 - Lisboa.

Cópia. Letra do séc. XIX. A fl. 222 v. 
B.N.L

F.G. 238 .

(Carta de $\mathrm{D}$. João V ao governador e capitão general da Capin tania de S. Paulo, sôbre se restituir a algumas Câmaras as quantias que tinham dado para o donativo, por S.M. ter resolvida perdoar-lho, ou se mandar aplicar essas quantias nalguma obra. pública).

1746. Maio, 6 - Lisboa.

Cópia. Letra do séc. XIX. A fl. 223.

B.N.L.

F.G. 238

(Carta enviada por Manuel Caetano Lopes do Lavre, a D. Luizde Mascarenhas, governador da capitania de S. Paulo, por ordeme do Conselho Ultramarino, remetendo-lhe as leis sobre o delito de misturar latão com ouro em pó, para que êle as faça executar). 1746. Maio, 8 - Lisboa.

Cópia. Letra do séc. XIX. A fl. 224.

B.N.L.

F.G. 238

(Carta de $\mathrm{D}$. João $\mathrm{V}$ ao governador e capitão general da Capitania de S. Paulo, remetendo-lhe cópia dos Regimentos que S.M. mandou passar aos Boticários, para que êle as faça executar). 1746. Maio, 7 - Lisboa.

Cópia. Letra do séc. XIX. A fl. 224.

B.N.L.

F.G. 238

(Carta de D. João V ao governador e capitão general da Capì tania de $\mathrm{S}$. Paulo, informando-o que resolveu que se estabeleça na Cidade de S. Paulo uma Junta de Missões em conformidade com as de Pernambuco e Maranhão).

1746. Maio, 8 - Lisboa.

Cópia. Letra do séc. XIX. A fl. 224 v.

B.N.L.

F.G. 238

(Carta de D. João V a D. Luiz de Mascarenhas, governador e capitão general da Capitania de $\mathrm{S}$. Paulo, ordenando-lhe que dê conta do recebimento dos direitos de entrada que se pagam pelas cavalgaduras na de Curitiba).

1746. Maio, $8 \sim$ Lisboa.

Cópia. Letra do séc. XIX. A fl. 225.

B.N.L.

F.G. 238

(Carta de D. João V ao governador e capitão general da Capitania de S. Paulo, informando-o de que se não deve conceder auxilio para as diligências de Juizes eclesiásticos).

1747. Abril, 11 - Lisboa.

Cópia. Letra do séc. XIX. A fl. 225 v.

B.N.L.

F.G. 238

(Carta de D. João V ao governador e capitão general da Capiヶ tania de S. Paulo, ordenando-lhe que execute a sua resoluçáo tomada para que as eleições dos capitães mores naquela capitania, 
se faça na forma do Regimento Geral das Ordenanças e leis es* travagantes que há nesta matéria).

1747. Abril, 18 - Lisboa.

Cópia. Letra do séc. XIX. A fl. 226.

B.N.L.

F.G. 238

(Carta de D. João $\mathrm{V}$ ao governador e capitão general da Capie tania de S. Paulo, informando-o que por Decreto de 15 de Abril ${ }^{\circ}$ de 1747, determinou que se entreguem ao Bispo da Capitania as casas do Ouvidor de S. Paulo, contiguas à Igreja em que há de ficar a cadeira episcopal).

1747. Abril, 22 - Lisboa.

Cópia. Letra do séc. XIX. A fl. 226 v.

B.N.L.

F.G. 238

(Carta de D. João V ao governador e capitão general da Capitania de S. Paulo, ordenando-lhe que se não impeça aos contra. tadores a cobrança das dizimas subseqüentes que se deverem na forma da lei, para que se não dê ocasião a que êles se queixem por não verem cumpridos os contratos que fazem com a Real Fazenda).

1747. Abril, 28 - Lisboa.

Cópia. Letra do séc. XIX. A fl. 226 v.

B.N.L.

F.G. 238

(Carta de D. João V ao governador e capitão general da Capi. tania de S. Paulo, informando-o que João Francisco rematou $a$ contrato do rendimento das passagens antigas da capitania de $S$. Paulo, por 3 anos; pelo que S.M. lhe ordena que cumpra as; condições do contrato).

1747. Abril, 30 - Lisboa.

Cópia. Letra do séc. XIX. A f1. 227.

B.N.L.

F.G. 238

(Cartz de D. João V a D. Luiz de Mascarenhas, governador e capitão general da capitania de $\mathrm{S}$. Paulo, informando-o que resolveu que o alto da serra de Mantiqueira sirva de limite às: Capitanias de S. Paulo e de Minas Gerais).

1747. Abril, $30 \div$ Lisboa.

Cópia. Letra do séc. XIX. A fl. 227.

B.N.L.

F.G. 238

(Carta de D. João $\mathrm{V}$ ao governador e capitão general da Capitania de S. Paulo, pedindo-lhe um parecer sôbre a representaçáodos oficiais da Câmara da Vila de Goratinguetá, em que pedem. um religioso do Carmo para a Ordem Terceira daquela Vila). 1747. Maio, 1 - Lisboa.

Cópia. Letra do séc. XIX. A fl. 227 v.

B.N.L.

F.G. 238

(Carta de D. João $\mathrm{V}$ ao governador e capitão general da Capitania de $\mathrm{S}$. Paulo, ordenando-lhe que dê tôdas as providências: 
necessárias para se fazer a cobrança dos direitos que pagam os gados e cavalgaduras que entram na capitania de S. Paulo pelo registo de Curitiba).

1747. Maio, 4 - Lisboa.

Cópia. Letra do séc. XIX. A fl. 227 v.

B.N.L.

F.G. 238

(Carta de D. João V ao Provedor da Fazenda Real da Capitania de S. Paulo e Santos, ordenando-lhe que dê toda a ajuda necessária aos missionários que vão para a aldeia das Minas dos Goiazes civilizar gentio).

1747. Julho, 17 - Lisboa.

Cópia. Letra do séc. XIX. A fl. 228.

B.N.L.

F.G. 238

(Carta de $\mathrm{D}$. João $\mathrm{V}$ ao governador e capitão general da Capltania de S. Paulo, informando-o que Pedro Gomes Moreira rematou o contrato dos dizimos do povoado de Santos, Capitania de S. Paulo, e Rio Grande de S. Pedro, por 3 anos, pelo que the ordena que cumpra as condiçōes do contrato).

1747. Maio, 9 - Lisboa.

Cópia. Letra do séc. XIX. A fl. 228.

B.N.L.

F.G. 238

(Carta de $\mathrm{D}$. João $\mathrm{V}$ ao governador e capitão general da Capitania de S. Paulo, dizendo-lhe as qualidades que devem ter as pessoas em quem se prover os oficios de escrivães das câmaras). 1747. Maio, 9 - Lisboa.

Cópia. Letra do séc. XIX. A fl. 228.

B.N.L. F.G. 238

(Carta de D. João V a D. Luiz de Mascarenhas, ordenando-lhe que diga a razão por que concordou com os excessos cometidos por Antônio de Sá Pereira, Capitão de Dragões das Minas dos Goiazes, dando-lhe ordens nesse sentido).

1747. Julho, 17 - Lisboa.

Cópia. Letra do séc. XIX. A fl. 228 v.

B.N.L.

F.G. 238

(Carta de D. João V a D. Luiz de Mascarenhas, governador e capitão general da capitania de $\mathrm{S}$. Paulo, ordenando-lhe que dê conta do que tem sucedido àcêrca do gentio que se pretende aldear nos arraiais da Natividade e Remédios, e a respeito das providências que se lhe mandaram dar).

1747. Julho, 19 - Lisboa.

Cópia. Letra do séc. XIX. A fl. 229.

B.N.L.

F.G. 238

(Carta de Marcos Antônio de Azevedo Coutinho a D. Luiz de Mascarenhas, informando-o que S.M. resolveu que se criassem 2 governos e capitanias gerais: a $1 .^{\mathrm{A}}$ no Mato Grosso com a comarca de Cuiabá até o Rio. Grande, e a $2{ }^{a}$ no Goyaz; e que a 
capitania de S. Paulo até Rio Grande com as adjacentes, atê os confins dos governos de Minas Gerais, Rio de Janeiro e da Itha de $S^{a}$. Catarina, fiquem administradas pelo governador de Santos que ficará subordinado ao do Rio de Janeiro; e que o governador das Minas Gerais examine e determine os sitios em que se deve fazer a extração dos diamantes no Rio Grande e dos Pilóes). 1748. Maio, 17 - Lisboa.

Cópia. Letra do séc. XIX. A fl. 229 v.

B.N.L.

F.G. 238

(Carta de D. João V ao governador e capitão general da Capitania de S. Paulo, dizendo-lhe que se não pode reformar ou impedir a execução dos provimentos dos corregedores; e a respeito da Câmara de S. Paulo, cumpra os capitulos do ouvidor da mesma comarca, e quando sôbre êles tenham que requerer, representem ao mesmo ouvidor para que os reforme, e se não lhes for deferido, ou agravem para a Relação da Bahia, ou dêm conta a S.M. pelo Conselho Ultramarino).

1748. Julho, 5 - Lisboa.

Cópia. Letra do séc. XIX. A fl. 230.

B.N.L.

F.G. 238

(Carta de D. João V ao governador e capitão general da Capitania de S. Paulo, informando-o que resolveu que os Ajudantes supra e do número de Infantaria da Praça de Santos, recebam o mesmo soldo que os do Rio de Janeiro).

1748. Julho, 6 - Lisboa.

Cópia. Letra do séc. XIX. A fl. 230.

B.N.L.

F.G. 238

(Carta de D. João V ao governador e capitão general da Capitania de $S$. Paulo, informando-o que mandou ir do Reino e llhas adjacentes, casais de colonos para a Ilha de Santa" Catarina, e que na Alfândega de Santos se faça o registo de tôdas as fazendas alfandegadas, que embarcarem para a Ilha de Santa Catarina, ou para outra qualquer parte do referido distrito).

1748. Agôsto, 5 - Lisboa.

Cópia. Letra do séc. XIX. A fl. 231.

B.N.L.

F.G. 238

(Carta de D. João V ao governador do distrito de S. Paulo, ordenando-lhe que faça a separação dos papéis que estão na Secretaria de S. Paulo, pertencentes aos governos de Goyaz e de Mato Grosso, e os mande entregar aos secretários respectivos).

1748. Setembro, 2 - Lisboa.

Cópia. Letra do séc. XIX. A fl. 231.

B.N.L.

F.G. 238

(Carta de D. João $\mathrm{V}$ ao governador e capitão general da Capitania de $S$. Paulo, pedindo-lhe informação sôbre a causa que houve para êle ter mandado ao Provedor do Rio de Janeiro o ouro daquela capitania sem guias nem relação distintas).

1748. Setembro, 12 - Lisboa.

Cópia. Letra do séc. XIX. A fl. 231 v. 
B.N.I.

F.G. 238

(Carta de D. José ao Ouvidor da Comarca de S. Paulo, dizendo-lhe que faça observar a constituição do Arcebispado da Bahia, na matéria de salários, e que tendo que fazer modificações, lhe dê conta). 1752. Fevereiro, 15 - Lisboa.

Cópia. Letra do séc. XIX. A fl. 236.

B.N.L. F.G. 238

(Carta de D. José ao governador da Praça de Santos e de S. Paulo, enviando o alvará em que ordena o tratamento de Senhoria e de Reverendíssimo Senhor ao Administrador Episcopal de Moçambique).

1759. Setembro, 13 - Lisboa.

Cópia. Letra do séc. XIX. A fl. 241.

B.N.L.

F.G. 238

(Carta de D. João V ao governador e capitão general da Capitania de S. Paulo, informando-o que nomeou o Bacharel Braz do Vale, para continuar nas devassas de cunhos a moedas falsas. na capitania de S. Paulo).

1733. Outubro, 30 - Lisboa.

Cópia. Letra do séc. XIX. A fl. 243.

B.N.L.

F.G. 238

(Carta de D. João V a Rodrigo César de Meneses, governador e capitão general da capitania de S. Paulo, pedindo um parecer sôbre os governadores obedecerem aos Vice-Reis e aos capitães generais do Estado e às ordens do Conselho Ultramarino).

1742. Novembro, $14-$ Lisboa.

Cópia. Letra do séc. XIX. A fl. 243.

B.N.L.

F.G. 467

(Memorial das vilas que tem a capitania de S. Paulo. Nomes das vilas com a distribuição das bulas da cruzada de cada uma). Cópia. Letra do séc. XVIII. A fl. 5.

B.N.L.

F.G. 598

(Noticia da independência da provincia dos Religiosos da $\mathrm{N}^{\mathrm{n}}$. $\mathrm{S}^{\mathrm{*}}$. do Carmo do Rio de Janeiro, em 1722; fundação do convento do Rio de Janeiro em 1585; fundação do de S. Paulo em 1599, etc.). Cópia. Letra do séc. XIX. $60^{\circ}$ fascículo. A pg. 10.

B.N.L.

F.G. 630

(Carta de Fr. Gaspar da Madre de Deus ao Secretário da Academia Brasílica dos Renascidos, àcêrca do encargo de escrever as memórias do Bispado de S. Paulo).

1759. Outubro, 22 - Rio de Janeiro.

Cópia. Letra do séc. XVIII. A fl. 138 .e 139. 
B.N.L.

F.G. 674

(Despachos Ministeriais de 7 de Abril de 1739, para Ouvidores do Ultramar: S. Paulo, Seará, Parnaguá, Paraiba, Rio de Janeiro e Espirito Santo).

Cópia. Letra do séc. XIX. A fl. 228.

B.N.L.

F.G. 4414

(Catálogo dos prelados e mais cargos da nossa provincia do Brasil, referindo-se a fl. 138 v. ao mosteiro de S. Paulo).

Cópia. Letra do séc. XVIII. A fl.' 138 v.

B.N.L.

F.G. 4530

(Relação de como principiou a provedoria da capitania de $\mathbf{S}$. Paulo, e do estado dela. - Pelo provedor da Fazenda da Capitania de S. Paulo, José de Goday Moreyra).

Cópia. Letra do séc. XVIII. A fl. 1 a 5.

B.N.L.

F.G. 4530

(Ofício de Martim Lopes Lobo de Saldanha, nomeado capitão general da Capitania de S. Paulo, ao Marquês de Pombal, participando-lhe a sua chegada ao Rio de Janeiro e referindo-se ao que dirigiu ao secretário Martinho de Melo e Castro, sóbre o que passou com o Marquês de Lavradio, vice-rei do Estado do Brasil). 1775. Abril, $24-$ Rio de Janeiro.

Original. A fl. 22.

B.N.L.

F.G. 4530

(Oficio de Martim Lopes Lobo de Saldanha, nomeado capitão general da Capitania de S. Paulo, ao secretário de Estado Martinho de Melo e Castro sôbre a sua chegada ao Rio de Janeiro e o. que passou com o vice-rei de Estado do Brasil, quanto às tropas que se haviam de formar em S. Paulo e enviar para o Rio Grande).

1755. Abril, 24 - Rio de Janeiro.

Cópia. Letra do séc. XVIII. A fl. 24.

B.N.L.

F.G. 4530

(Oficio do Marquês do Lavradio, vice-rei do Estado do Brasil, a Martim Lopes Lobo de Saldanha sôbre o modo por que julga que êste deve executar as instruçóes que recebeu de S.M. para governar a Capitania de S. Paulo).

1775. Maio, 27 - Rio de Janeiro.

Cópia autêntica. Letra do séc. XVIII.

A fl. 26. Outra igual a fl. 34 .

B.N.L.

F.G. 4530

(Relação de todos os pagamentos que fêz o tesoureiro Antônio José Pinto por ordem do general D. Luiz Antônio de Souza Botelho Mourão, antecessor do presente govêrno e da preterida Real Fazenda desta Capitania de S. Paulo, desde 17 de abril a 13 de Junho de 1775).

Cópia. Letra do séc. XVIII. A fl. 43. 
B.N.L.

F.G. 4530

(Bando em nome do governador da Capitania de S. Paulo, perdoando a tôdas as pessoas tanto paisanas como militares que haviam fugido da dita Capitania ou nela estavam ocultas).

1775. Junho, 17 - S. Paulo.

Cópia autêntica. Letra do séc. XVIII.

A fl. 44. Outra igual a fl. 45.

B.N.L.

F.G. 4530

(Certidão do ouro que entrou na Real Casa da Fundição da cidade de S. Paulo de 1 de Janeiro até 23 de Março de 1775, do rendimento do quinto e de como foi enviado à tesouraria geral do Rio de Janeiro).

1755. Junho, $22-$ S. Paulo.

Cópia autêntica. Letra do séc. XVIII. A fl. 46.

B.N.L.

F.G. 4530

(Informação dada por Luiz Antônio de Sousa Botelho Mourão a Martim Lopes Lobo de Saldanha que lhe sucedeu no govêrno da Capitania de S. Paulo șôbre o estado da dita Capitania). 1775. Junho, 23 - S. Paulo.

Cópia autêntica. Letra do séc. XVIII. A fl. 48 a 64.

B.N.L.

F.G. 4530

(Carta régia a D. Luiz Antônio de Souza Botelho Mourão para que entregue o govêrno da Capitania de $\mathrm{S}$. Paulo, de que era governador, a Martim Lopes Lobo de Saldanha que the vai suceder).

1775. Janeiro, 2 - Lisboa.

Cópia autêntica. Letra do séc. XVIII. A fl. 65.

B.N.L.

F.G. 4530

(Martim Lopes Lobo de Saldanha - Notas às instruções juntas que the entregou D. Luiz Antônio de Sousa Botelho Mourão, governador da Capitania de S. Paulo, quanto lhe deu a posse do govêrno da dita Capitania).

1775. Novembro, 30 - S. Paulo.

Cópia. Letra do séc. XVIII. A fl. 66 a 71 .

B.N.L.

F.G. 4530

(Portaria nomeando Pedro da Silva para sargento-mor do regimento de infantaria paga da Capitania de S. Paulo).

1775. Julho, 1 - S. Paulo.

B.N.L

Cópia autêntica. Letra do séc. XVIII. A fl. 74.

F.G. 4530

(Carta de Fr. Manuel, bispo de S. Paulo, a José Gomes da Costa, sôbre José Gomes Pinto, Ouvidor e Corregedor da comarca de $\mathrm{S}$. Paulo, e relatando o que êste sofreu do ex-capitão general $\mathrm{D}$. Luiz Antônio de Souza Botelho Mourão, cujo govêrno criminoso e tirano descrevej.

1775. Julho, $6-$ S. Paulo.

Original. A fl. 75 . 
B.N.L.

F.G. 4530

(Requerimento de Raimundo José de Souza para se lhe pagarem os soldos de capitão de granadeiros do regimento S. Paulo, e despachos que sôbre êle se proferiram).

1775. Julho, 6, 7, $12-\mathrm{S}$. Paulo.

Cópia. Letra do séc. XVIII. A fl. 77.

B.N.L.

F.G. 4530

(Portaria às Câmaras de S. Paulo, para que proponha 3 pessoas para cada oficio de escrivão da Real Casa da Fundição da dita cidade e para que nomeie o tesoureiro e fiscais da mesma).

1775. Julho, 19 - S. Paulo.

Cópia autêntica. Letra do séc. XVIII.

A fl. 82. Outra igual a fl. 83 .

B.N.L.

F.G. 4530

(Carta de José Custódio de Sá e Faria ao governador da Capitania de $\mathrm{S}$. Paulo, sôbre as relações da Praça de $\mathrm{N}^{\mathrm{a}}$. $\mathrm{S}^{\mathrm{a}}$. dos Prazeres do Rio Igatemi que governava, e o capitão general da provincia de Paraguai).

1775. Julho, 20 - Praça de $N^{n}$. $S^{n}$. dos Prazeres.

Cópia autêntica. Letra do séc. XVIII. A fl. 84.

B.N.L.

F.G. 4530

(Carta de José Custódio de Sá e Faria, governador de $\mathrm{N}^{\mathbf{n}}$. $\mathrm{S}^{\mathbf{a}}$. dos Prazeres de Igatemi, ao governador da Capitania de S. Paulo, sôbre a demora que teve em ir tomar conta daquela praça).

1775. Julho, $20-$ Praça de $N^{a}$. $S^{a}$. dos Prazeres.

(Acompanhavam-na uma relação das munições de guerra, artilharia e petrechos que se achavam na mesma praça, outra dos remédios pedidos pelo seu cirurgião, e outrà do que se precisa na dita praça para a ferraria, para os doentes e para a tropa).

Cópias autênticas. Letra do séc. XVIII.

A fl. 89 e 91 a 93 .

B.N.L.

F.G. 4530

(Oficio de José Custódio de Sá e Faria ao governador da capitánia de $\mathrm{S}$. Paulo, sôbre as relações da Praça de $\mathrm{N}^{\mathrm{a}}$. $\mathrm{S}^{\mathrm{n}}$. dos Prazeres de Igatemi que governava, e o capitão general de Parnaguá).

1775. Julho, 20 - Da dita Praça.

Cópia. Letra do séc. XVIII. A fl. 94.

B.N.L.

F.G. 4530

(Portaria às Câmaras, Justiça e Capitães auxiliares das Vilas de Mogi-guassú e de Mogi-mirim para darem tôda a ajuda e favor ao sargento Jerônimo Dias Ribeiro, comandante de Registo de S. Mateus das Cabeceiras do R. Pardo, a quem o governador da Capitania de S. Paulo, encarregou do caminho novo que vai de Mogi-guassú até o descoberto de $\mathrm{N}^{\mathrm{a}}$. $\mathrm{S}^{\mathrm{a}}$. de Bom Sucesso).

1775. Setembro, $2-$ S. Paulo.

Cópia autêntica. Letra do séc. XVIII. A fl. 95. 
B.N.L.

F.G. 4530

(Ordem do governador da capitania de S. Paulo, para serem trancados todos os caminhos que vão para o Jacuhi, excepto o do registo de $\mathrm{S}$. Mateus, e mais disposiçōes a tal respeito, o que está encarregado de dirigir o sargento Jerônimo Dias Ribeiro, com o que se fiscalizarão melhor os interếsses da fazenda, e não se dificultarão os transportes para Minas).

1775. Setembro, $2-S$. Paulo.

Cópia. Letra do séc. XVIII. A fl. 97.

B.N.2.

F.G. 4530

(Portaria do governador da Capitania de S. Paulo pela qual manda que os pagamentos que se fizerem tanto aos ajudantes das ordens, como aos da cavalaria auxiliar para o sustento dos cavalos em que exercitam seus postos seja a 160 réis por dia e não a 320).

1775. Setembro, 12 - São Paulo.

Cópia autêntica. Letra do séc. XVIII. A fl. 99.

Outra igual a fl. 100.

B.N.L.

F.G. 4530

(Edital do governador da Capitania de S. Paulo proibindo às mulheres andarem rebuçadas ou com chapéus sôbre o manto ou baeta).

1775. Setembro, 23 - S. Paulo.

Cópia autêntica. Letra do séc. XVIII. A fl. 102.

B.N.L.

F.G. 4530

(Traslado dos autos de averiguação que se fêz por testemunhas e documentos na Junta da Real Fazenda da Capitania de $S$. Paulo, sôbre a representação que fêz o Dr. Ouvidor José Gomes Pinto de Morais a respeito das nulidades com que se rematou o contrato dos dizimos, e de se dever resarcir a Real Fazenda dos prejuizos que padeceu e dos lucros que lhe pertencem). 1775. Outubro, 3 - S. Paulo.

Cópia. Letra do séc. XVIII. A fl. 103 a 120.

B.N.L. F.G. 4530

(Edital do governador da Capitania de S. Paulo, com diversas providências para impedir os males que vinham à cidade de $\mathrm{S}$. Paulo dos atravessadores de gêneros).

1775. Outubro, $5-$ S. Paulo.

Cópia autêntica. Letra do séc. XVIII. A fi. 121.

B.N.L.

F.G. 4530

(Edital pelo qual o governador da Capitania de S. Paulo manda que tanto nos acompanhamentos como nos ofícios se não dê cera senão aos eclesiásticos oficiantes).

1775. Outubro, $14-\mathrm{S}$. Paulo.

$\sin a$

Cópia. Letra do séc. XVIII. A fl. 122. 
B.N.L.

F.G. 4530

(Ofício de Martim Lopes Lobo de Saldanha ao Marquês de Pombal, sôbre a nomeação de escrivão, tesoureiro e fiscais da Real Casa da Fundição da Cidade de S. Paulo).

1775. Novembro, $4-$ S. Paulo.

Original. A fl. 123.

B.N.L.

F.G. 4530

(Carta enviada da Câmara de Goratinguetá ao governador da Capitania de S. Paulo, para que se obtenha de S.M. a proibição do fabrico dos tabacos em Minas, a fim de terem mais extração os da dita capitania).

1775. Novembro, $4-$ Goratinguetá.

Cópia autêntica. Letra do séc. XVIII. A fl. 124.

B.N.L.

F.G. 4530

(Oficio de Martim Lopes Lobo de Saldanha ao Marquês de Pombal em que declara haver determinado que os moradores das vilas da sua Cápitania que passarem à de Minas, com excepção dos solteiros, aos que todos pretendia alistar, se legitimassem pela policia perante as justiças das mesmas vilas).

1775. Novembro, 5 - S. Paulo.

Original. A fl. 126.

B.N.L:

F.G. 4530

(Ofício de Martim Lopes Lobo de Saldanha, governador da $\mathrm{Ca}$ pitania de S. Paulo, ao Marquês de Pombal, sôbre a pobreza em que se encontra a Mesa da Misericórdia de S. Paulo, e que S.M. permita que cada pessoa no tempo da Desobriga dê 10 réis, cobrados pelos párocos, para acudir às muitas necessidades da dita Misericórdia de S. Paulo).

1775. Novembro, $6-$ S. Paulo.

Original. A fl. 127.

B.N.L.

F.G. 4530

(Ofício de Martim Lopes Lobo de Saldanha, governador da Capitania de S. Paulo, ao Marquês de Pombal, sôbre o novo caminho que está fazendo para o Rio de Janeiro em 22 léguas de caminho que mandou abrir nos matos, e sôbre os concertos a que procedeu no caminho pela marinha para Santa Catarina.)

1775. Novembro, $10-$ S. Paulo.

Original. A fl. 128.

B.N.L.

F.G. 4530

(Oficios [2] de Martim Lopes Lobo de Saldanha, governador da capitania de S. Paulo, ao Marquês de Pombal, sôbre a fatura de edificios para morada dos governadores da dita capitania e para o tesouro, junta, contadores, e secretaria de que havia falta). 1775. Novembro, 11 e 19 - S. Pat1lo.

Original. A fl. 131 e 139. 
B.N.L.

F.G. 4530

(Oficio de Martim Lopes Lobo de Saldanha, governador da Capitania de S. Paulo, ao Marquês de Pombal, sôbre as instruções que lhe deu o seu antecessor e notas feitas a estas para êle, governador da Capitania de S. Paulo (vide fl. 48 e 60), e como. se retirou sem lho dizer).

1775. Novembro, $13 \sim \mathrm{S}$. Paulo.

Original. A fl. 132.

B.N.L.

F.G. 4530

(Oficio de Martim Lopes Lobo de Saldanha, governador da Capitania de S: Paulo, ao Marquês de Pombal, sôbre a necessidade que havia em $\mathrm{S}$. Paulo de armazens e quartéis para as tropas, de um hospital além do da misericórdia, ainda nāo acabado).

1775. Novembro, $14^{-}-$S. Paulo.

Original. A fl. 133.

B.N.L.

F.G. 4530

(Oficio de Martim Lopes Lobo de Saldanha, governador da Capitania de S. Paulo, ao Marqués de Pombal, sôbre o bando que fêz publicar para as mulheres em $\mathrm{S}$. Paulo não andarem rebuçadas ou com chapéus, etc. (vide fl. 102).

1775. Novembro, 17 - S. Paulo.

Original. A fl. 134.

B.N.L.

F.G. 4530

(Carta enviada da Câmara de Vila Nova de S. Luiz de Paraitinga ao governador da Capitania de S. Paulo, para que obtenha de S.M. a proibição do fabrico dos tabacos em Minas a fim de terem mais extração os da dita Capitania.

1775. Novembro, $18-V^{\mathrm{a}}$. $\mathrm{N}^{\mathrm{a}}$. de $\mathrm{S}$. Luiz de Paraitinga.

B.N.L.

Cópia autêntica. Letra do séc. XVIII. A fl. 135.

F.G. 4530

(Carta enviada da Câmara de $V^{n}$. de Pindamonhangaba ao governador da Capitania de S. Paulo, para que obtenha de S.M. a proibição do fabrico dos tabacos em Minas a fim de que tenham mais extração os da dita Capitania).

1775. Novembro, 19 - S. Paulo.

B.N.L.

Cópia. Letra do séc. XVIII. A fl. 137.

F.G. 4530

(Ofício de Martim Lopes Lobo de Saldanha, governador da Capitania de S. Paulo, ao Marquês de Pombal, sôbre a baixa que deu a Raimundo José de Santos, nomeado ilegalmente por seu antecessor, Capitão de Granadeiros).

1775. Novembro, $25-\mathrm{S}$. Paulo.

Original. A f1. 140.

B.N.L.

F.G. 4530

(Relação dos oficiais a que o governador de S. Paulo, Martim Lopes Lobo de Saldanha, deu baixa em S. Paulo dos que achou providos incompetentemente $e$ incapazes).

Original. A fl. 141.

Outra igual a fl. 142. 
B.N.L.

F.G. 4530

(Oficio de Martim Lopes Lobo de Saldanha, governador da Capitania de S. Paulo, ao Marquês de Pombal, sôbre os estragos. que faziam as bexigas nos moradores da cidade de S. Paulo e nas companhias de. soldados que mandou para o Rio Grande). 1775. Novembro, $29-$ S. Paulo.

Original. A fl. 143.

B.N.L.

F.G. 4530

(Oficio de Martim Lopes Lobo de Saldanha, governador da Capitania de S. Paulo, ao Marquês de Pombal, sôbre a formação. de regimento de Voluntários Reais, acompanhado da relação dos nomes, naturalidades, idades, tempo de serviço, postos em que se achavam e préstimos dos oficiais providos no dito regimento) 1775. Dezembro, $1-$ S. Paulo.

Original. A fl. 144 e 145 a 152.

B.N.L.

F.G. 4530

(Oficio de Martim Lopes Lobo Saldanha, governador da capitania de S. Paulo, ao Marquês de Pombal, sôbre a portaria que fizeram expedir reduzindo os soldos dos ajudantes de ordens e dos. auxiliares, ao que era devido, emendando assim o abuso do seu. antecessor).

1775. Dezembro, 2 - S. Paulo.

Original. A fl. 153.

B.N.L.

F.G. 4530

(Ofício de Martim Lopes Lobo de Saldanha, governador da Capitania de S. Paulo, ao Marquês de Pombal, sôbre a nomeação. que fêz para seu segundo ajudante de ordens, Francisco Antônio. Alfeirão e recomendando-o a S.M. para o posto de Capitão). 1775. Dezembro, 3 - S. Paulo.

Original. A fl. 154.

B.N.L.

F.G. 4530

(Ofício de Martim Lopes Lobo de Saldanha, governador da Capitania de S. Paulo, ao Marquês de Pombal sôbre o modo porque fardou o regimento de infantaria de $\mathrm{S}$. Paulo e a legião de Voluntários Reais, e do que convém fazer-se para o futuro a tal. respeito).

1775. Dezembro, 4 - S. Paulo.

Uriginal. A fl. 155.

B.N.L.

F.G. 4530

(Ofício de Martim Lopes Lobo de Saldanha, governador da Ca pitania. de S. Paulo, ao Marquês de Pombal, sóbre o preço porque determinou se fizessem fardas e calçado para a tropa).

1775. Dezembro, $5-\mathrm{S}$. Paulo.

Original. A fl. 156. 
B.N.L.

F.G. 4530

(Oficio de Martim Lopes Lobo de Saldanha, governador da Capitania de S. Paulo, ao Marquês de Pombal, sôbre a necessidade de outro quartel mestre para a legião dos Voluntários Reais). 1775. Dezembro, 6 - S. Paulo.

Original. A fl. 157.

B.N.L.

F.G. 4530

(Oficio de Martim Lopes Lobo de Saldanha, governador da Capitania de S. Paulo, ao Marquês de Pombal, sôbre o modo porque formou o regimento de $S$. Paulo e estado em que o achou). 1775. Dezembro, 7 - S. Paulo.

Original. A fl. 158.

B.N.L.

F.G. 4530

(Oficio de Martim Lopes Lobo de Saldanha, governador da $\mathrm{Ca}$ pitania de S. Paulo, ao Marquês de Pombal, sôbre a formação do regimento de $S$. Paulo, acompanhado da relação dos nomes, naturalidades, idades, tempo de serviço, postos em que se achavam e préstimos dos oficiais providos no dito regimento).

1775. Dezembro, $12-\mathrm{S}$. Paulo.

Original. A fl. 159 e 160 a 163.

B.N.L.

F.G. 4530

(Trânsitos por onde marchou a infantaria de Voluntários Reais desta cidade de S. Paulo para o exército do Sul).

1775. Dezembro, 8 - S. Paulo.

Cópia autêntica. Letra do séc. XVIII. A fl. 164.

B.N.L.

F.G. 4530

(Carta enviada da Câmara de Mogi das Cruzes, ao governador da Capitania de S. Paulo, Martim Lopes Lobo de Saldanha, para obter de S.M. ordem para que a cultura do tabaco e da cana que se faz nas Minas Gerais, Goiazes e Cuiabá seja só privativa da Capitania de S. Paulo, com o que se evitarão os grandes preiuizos que a mesma sofre).

1775. Dezembro, 9 - Mogi das Cruzes.

Cópia autêntica. Letra do séc. XVIII. A fl. 165.

B.N.L.

F.G. 4530

(Oficio de Martim Lopes Lobo de Saldanha, governador da capitania de S. Paulo, ao Marquês de Pombal, pedindo abarracamentos para as tropas que enviou para o Sul).

1775. Dezembro, $9-$ S. Paulo.

Original. A fl. 167.

B.N.L.

F.G. 4530

(Ofício de Martim Lopes Lobo de Saldanha, governador da Capitania de S. Paulo, ao Marquês de Pombal, sôbre o modo por que armou de clavinas os capitães da cavalaria da legião de Voluntários Reais, aproveitando um armamento velho).

1775. Dezembro, 10 - S. Paulo.

Original. A fl. 168. 
B.N.L.

F.G. 4530

(Ofício de Martim Lopes Lobo de Saldanha, governador da Capitania de S. Paulo, ao Marquês de Pombal, dizendo-lhe que não aquartela as tropas na Vila das Lages e outros lugares imediatos ao exército por estar expedindo para êle tôdas as tropas pagas, e que tem algumas companhias de auxiliares em Curitiba para socorrer a dita Vila se fôr preciso).

1775. Dezembro, 11 - S. Paulo.

Original. A fl. 169.

B.N.L.

F.G. 4530

(Oficio de Martim Lopes Lobo de Saldanha, governador da Capitania de S. Paulo, ao Marquês de Pombal, sóbre o modo porque mandou por mar as tropas para o Sul).

1775. Dezembro, $12-\mathrm{S}$. Paulo.

Original. A fl. 170.

B.N.L

F.G. 4530

(Oficio de Martim Lopes Lobo de Saldanha, governador da Capitania de S. Paulo, ao Marquês de Pombal, sôbre as ajudas de custo que se davam aos oficiais das tropas em marcha, abuso que êle tirou quando enviou as fôrças para o Sul).

1775. Debembro, 13 - S. Paulo.

Original. A fl. 171.

(Acompanha-o um documento sôbre o que a tal respeito se praticava no Rio de Janeiro). A fl. 172.

B.N.L.

F.G. 4530

(Oficio de Martim Lopes Lobo de Saldanha, governador da Capitania de S. Paulo, ao Marquês de Pombal, sôbre as razōes por que deu baixa do posto de coronel do regimento de S. Paulo a Afonso Botelho de Sampaio).

1775. Dezembro, $16-$ S. Paulo.

Original. A fl. 173 e 174.

(Com documento explicativo a fl. 175).

B.N.L.

F.G. 4530

(Ofício de Martim Lopes Lobo de Saldanha, governador da Capitania de S. Paulo, ao secretário de Estado Martinho de Melo e Castro, sôbre o miserável estado em que deixou a dita capitanla o seu antecessor D. Luiz Antônio de Sousa Botelho Mourão, pelo seu escandaloso govêrno).

1775. Dezembro, 18 - S. Paulo.

Original. A fl. 176 a 184.

B.N.L.

F.G. 4530

(Ofício de Martim Lopes Lobo de Saldanha, governador da Capitania de S. Paulo, ao Marquês de Pombal, sôbre o cumprimento das instruçôes que the deu o vice-rei do Brasil para o govêrno da dita capitania, principalmente acêrca das pessoas que dela andavam fugidas pela má administração do seu antecessor).

1775. Dezembro, 19 - S. Paulo.

Original. A fl. 186. 
B.N.L.

F.G. 4530

(Oficio de Martim Lopes Lobo de Saldanha, governador da Capitania de S. Paulo, ao Marquês de Pombal, sôbre a ordem que deu (vide fl. 95 a 97) para serem trancados todos os caminhos que vão para o Jacuhy, excepto o do registo de S. Mateus, para melhor fiscalização dos interêsses da Fazenda).

1775. Dezembro, $29 \sim$ S. Paulo.

Original. A fl. 187.

B.N.L.

F.G. 4530

(Ofício de Martim Lopes Lobo de Saldanha, governador da Capitania de S. Paulo, ao Marquês de Pombal, ponderando a falta que há em $\mathrm{S}$. Paulo de uma cadeia pública, e como se há-de fazer).

1775. Dezembro, $21-$ S. Paulo.

Original. A fl. 188.

B.N.L.

F.G. 4530

(Oficio de Martim Lopes Lobo de Saldanha, governador da Cam pitania de S. Paulo, ao Marquês de Pombal, sôbre a baixa que: deu a Antônio Lopes de Azevedo do posto de sargento mor). 1775. Dezembro, 23 - S. Paulo.

Original. A fl. 189.

B.N.L.

F.G. 4530

(Oficio de Martim Lopes Lobo de Saldanha, governador da Capitania de S. Paulo, ao Marquês de Pombal, sôbre a reposiçăo dos soldos que o sargento mor António Lopes de Azevedo provida. ilegalmente devia fazer).

1775. Dezembro, $24-$ S. Paulo.

Original. A fl. 190.

B.N.L.

F.G. 4530

(Carta enviada da Câmara da cidade de S. Paulo ao governador da Capitania, Martim Lopes Lobo de Saldanha, para que obtenha de S.M. a proibição de se fabricarem a cana de açúcar e o fumo nas Minas Gerais, Goiazes e Mato Grosso, com o que se melhora - estado precário da dita capitania).

1775. Dezembro, 27 - S. Paulo.

Cópia autêntica. Letra do séc. XVIII. A fl. 191.

B.N.L.

F.G. 4530

(Oficio de Martim Lopes Lobo de Saldanha, governador da Capitania de S. Paulo, ao Marquês de Pombal, com as razões por que deu baixa do lugar de auditor a José Vaz de Carvalho).

1775. Dezembro, 28 - S. Paulo.

B.N.L.

Original. A fl. 193.

F.G. 4530

(Certidão do contador geral da capitania de S. Paulo, Matias José Ferreira Abreu, do que existia nos cofres da Real Fazenda). 1775. Dezembro, 23 - S. Paulo.

Cópia. Letra do séc. XVIII. A fls. 194. 
B.N.L.

F.G. 4530

(Carta enviada da Câmara da Vila de Jacarai (Capitania de S. Paulo), ao Governador da Capitania de S. Paulo, Martim Lopes Lobo de Saldanha, para que obtenha de S.Mag. a proibição do fabrico da cana de açúcar nas Minas Gerais, Goiazes e Cuiabá, com o que se evitará o prejuizo que por isso sofre a dita $\mathrm{Ca}$ pitania).

1775. Dezembro, 30 - Jacarai.

Cópia autêntica. Letra do séc. XVIII. A fls. 195.

B.N.L.

F.G. 4530

(Oficio de Martim Lopes Lobo de Saldanha, governador da $\mathrm{Ca}$ pitania de S. Paulo, ao Marquês de Pombal, acompanhando 3 relações: uma dos oficiais a que deu baixa nas sete capitanias que achou; outro dos oficiais que agregou, uns no respectivo regimento e outros nas fortalezas; e outra dos que reformou).

1775. Dezembro, $30-$ S. Paulo.

Original. A fls. 197 a 203.

(Tem em seguida as duas últimas relações em duplicado).

B.N.L.

F.G. 4530

(Oficio de Martim Lopes Lobo de Saldanha, governador da capitania de S. Paulo, ao Marquês de Pombal, sôbre as devassas tiradas contra os passadores e extraviadores de diamantes-brutos). 1776. Janeiro, 2 - S. Paulo.

Cópia. Letra do séc. XVIII. A fls. 204.

B.N.L.

F.G. 4530

- (Ofício de Martim Lopes Lobo de Saldanha, governador da Capitania de S. Paulo ao Marquês de Pombal, pedindo providências sôbre o livro mestre para a legião de Voluntários Reais da dita capitania).

1776. Janeiro, 3 - S. Paulo.

Original. A fls. 206.

B.N.L.

F.G. 4530

(Oficio de Martim Lopes Lobo de Saldanha, governador da Capitania de S. Paulo, ao Marquês de Pombal, acompanhando diversas representaçōes de câmaras da dita capitania, para a proibição do fabrico de cana de açúcar e de tabaco nas Minas Gerais, Goiazes e Cuiabá, a fim de melhorar o estado da mesma capitania). As representaçóes a que se alude vão nos lugares que thes competem pelas datas).

1776. Janeiro, $\cdot 13$.

B.N.I.

F.G. 4530

(Trânsitos por onde marchou a cavalaria de Voluntários Reais desta Cidade de S. Paulo para o exército do Sul).

1776. Janeiro, $16-\mathrm{S}$. Paulo.

Cópia autêntica. Letra do séc. XVIII. A fls. 208. 
B.N.L.

F.G. 4530

(Ofício de Martim Lopes Lobo de Saldanha, governador da Capitania de S. Paulo, ao Marquês de Pombal, sôbre os levantamentos de Ubatuba e providências que deu para reduzir e castigar.

1776. Janeiro, 18 - S. Paulo.

Original. A fls. 211.

(Antecedero a portaria que para êste fim expedido, em duplicado). A fls. 209 e 210.

B.N.L.

F.G. 4530

(Carta de João Henrique de Bohm, ao governador da Capitania: de S. Paulo, sôbre as tropas que dela foram para o exèrcito do Sul).

1776. Janeiro, 22 - Fronteira do Norte.

Cópia autêntica. Letra do séc. XVIII.

A fls. 212.

B.N.L

F.G. 4530

(Ofício de Martim Lopes Lobo de Saldanha, governador da $\mathrm{Ca}$ pitania de S. Paulo, ao Marquês de Pombal, acompanhando vários documentos, alguns dos quais ou todos vão nos lugares que lhes competem pelas datas, sôbre a praça de N. Sra. dos Prazeres de Igatemi, sôbre cuja inutilidade e estado faz largas considerações).

1776. Janeiro, 26 - S. Paulo.

Original. A fls. 215.

B.N.L.

F.G. 4530

B.N.L.

F.G. 4530

(Oficio de Martim Lopes Lobo de Saldanha, governador da Capitania de S. Paulo, ao Marquês de Pombal, sôbre a redução que se começou a fazer do gentio da freguesia de Santa Ana e dos meios brandos por que determina que se prossiga.

1776. Fevereiro, 1 - S. Paulo.

Original. A fl. 218.

(Ofício de Martim Lopes Lobo de Saldanha, governador da Capitania de S. Paulo, ao Marquês de Pombal, relatando que fizera vir da Praça de N. S. dos Prazeres de Igatemi, o brigadeiro José Custódio de Sá e Faria, por ter ali acabado as averiguações a que fôra, e que o encarregara de examinar as fortalezas e tôda a marinha para as fortificar, incumbencia que deixa agora por ser chamado ao Rio de Janeiro pelo vice-rei).

1776. Fevereiro, $7-$ S. Paulo.

B.N.L.

Original. A fl. 219.

F.G. 4530

(Ofício de Martim Lopes Lobo de Saldanha, governador da $\mathrm{Ca}$ pitania de S. Paulo; ao Marquês de Pombal, sôbre a remessa de tropas para o exército do Sul, feita por êste governador, e sôbre - ofício que lhe dirigiu àcêrca do mesmo assunto. João Henrique de Bohm (vide fl. 212).

1776. Fevereiro, $14-$ S. Paulo.

Original. A f1. 222. 
B.N.L.

F.G. 4530

(Certidão do escrivão da Junta da Real Fazenda da Capitania de S. Paulo, Matias José Ferreira Abreu, do que pagou por conta do $10^{\circ}$ pagamento do contrato dos dizimos da dita Capitania, $\mathrm{Ma}$ nuel José Gomes, seu contratador, e de como nos livros dos Têrmos das Arrematações, está o têrmo do mesmo contrato).

1776. Feverei $0,14-\mathrm{S}$. Paulo.

Cópia. Letra do séc. XVIII. A fl. 223.

B.N.L.

F.G. 4530

(Oficio de Martim Lopes Lobo de Saldanha, governador da Capitania de S. Paulo, ao Marquês de' Pombal, sôbre os trabalhos que tem passado no governo da dita capitania, formação de tro$\mathrm{pa}$, modo por que foi para o exército do Sul, e conveniência de esta ser mandada no futuro, por mar).

1776. Fevereiro, $17-\mathrm{S}$. Paulo.

Original. A fl. 224 a 226.

B.N.L.

F.G. 4530

(Oficio de Martim Lopes Lobo de Saldanha, governador da capitania de S. Paulo, ao Marquês de Pombal, para que o bispo de S. Paulo possa ordenar os presbiteros que forem necessários para paroquiar as aĺdeias dos indios e evitar o mal que provém de ser remediada esta falta por presbiteros regulares, e para que se mande ao dito bispo que nomeje pessoas idôneas em quatro cadeiras vagas de cônegos da sua sé e nos lugares de chantre e tesoureiro-mor; numa das quais cadeira pede que seja provido o padre Manuel Leandro Coreão).

1776. Fevereiro, 20. - S. Paulo.

Original. A fl. 227.

B.N.L.

F.G. 4530

(Oficio de Martim Lopes Lobo de Saldanha, governador da Capitania de S. Paulo, ao Marquês de Pombal, sôbre a vaga da Secretaria daquêle Govêrno, $e$ as pretençōes que a ela tem, José Honório de Valadares e Áboim deposto do abolido lugar de Provedor, pelo que não está conveniente conceder-lhe aquêle lugar, e lembrando para êle Carlos de Brito, filho do Dr. José Pereira de Brito).

1776. Fevereiro, 22 - S. Paulo.

Original. A fl. 229.

B.N.L.

F.G. 4530

(Oficio de José Custódio de Sá e Faria ao governador da Capitania de S. Paùlo, Martim Lopes Lobo de Saldanha, dando-lhe conta da comissão de que êle o incumbio de examinar as fortificações maritimas da dita capitania).

1776. Fevereiro, $22-$ S. Paulo.

Cópia autêntica. Letra do séc. XVIII. A fl. 230 a 232.

B.N.L.

F.G. 4530

(Oficio de Martim Lopes Lobo de Saldanha, governador da Capitania de S. Paulo, ao Marquês de Pombal, sôbre a má situação 
financeira em que se encontra pelo que lhe pede que the faça pagar as rendas e soldos do tempo em que esteve preso e suspenso, para satisfazer ao seu correspondente o que lhe deve; $\mathrm{e}$ lembrando-lhe ao mesmo tempo as mercês que S.M. Ihe fêz de 2 comendas de 600 mil réis e de uma alcaidaria-mor, pelos serviços de D. Bernardo de Fresneda, avô de sua mulher, e pelos de seu sogro em atenção à comenda da casa da India que a sua casa tinha).

1776. Fevereiro, $28-$ S. Paulo.

Original. A fl. 233 e 234 .

B.N.L,

F.G. 4530

(Ofício de Martim Lopes Lobo de Saldanha, governador da Capitania de S. Paulo, ao Marquês de Pombal, elogiando as qualidades e serviços do ouvidor da Comarca, José Gomes Pinto, e pedindo para o mesmo ser conservado no dito lugar, durante o seu govêrno ou com a beca de alguma relação conforme merece, e sôbre o casamento do mesmo ouvidor).

1776. Março, 2 - S. Paulo.

Original. A fl. 235 e 236.

B.N.L.

F.G. 4530

(Certidão do escrivão da Junta da Real Fazenda de se achar lançado no livro da receita e despesa das vendas reais da Capitania de S. Paulo o dinheiro que entregou Afonso Botelho de Sampaio e Souza, pelo duplicado de soldo de coronel de dragöes auxiliares, que se the tinha pago e pelo soldo que incompetentemente recebeu de ajudante de ordens, assim como o que pagaram seus fiadores).

1776. Março, 6 - S. Paulo.

Cópia. Letra do séc. XVIII. A fl. 237.

B.N.L.

F.G. 4530

(Ofício de Martim Lopes Lobo de Saldanha, governador da $\mathrm{Ca}$ pitania de S. Paulo, ao Marquês de Pombal, participando-lhe que nomeou interinamente para o lugar de secretário do dito govêrno, vago pela passagem de Tomaz $\mathrm{P}^{\circ}$. da Silva para a secretaria do Rio de Janeiro, ao seu secretário particular José Inácio Ribeiro Ferreira, e pedindo-lhe que não confirmando esta nomeação, ou não provendo no mencionado lugar a Carlos Brito, que lhe foi recomendado, escolha um sujeito hábil em quem possa descançar; pede-lhe também de novo, a recondução do ouvidor José Gomes Pinto).

1776. Abril, 20 - S. Paulo.

Original. A fl. 238.

B.N.L.

F.G. 4530

(Provisão do Governador da Capitania de S. Paulo, Martim Lopes Lobo de Saldanha, nomeando o Dr. José Inácio Ribeiro Ferreira para o lugar de secretário do dito govêrno, vago pela passagem de Tomaz $\mathrm{P}^{\circ}$. da Silva para secretário do govêrno do Rio de Janeiro).

1776. Abril, 19 - S. Paulo.

Cópia autêntica. Letra do séc. XVIII. A fl. 240. 
B.N.L.

F. G. 4530

(Exposição dos motivos que apresentam as capitanias de $\mathrm{S}$. Paulo e Minas Gerais sôbre as suas respectivas demarcações àcêrca das quais contendiam).

1779. Dezembro, 15.

Cópia. Letra do séc. XVIII. A fl. 241 a 244.

B.N.L.

F.G. 4530

(Considerações sôbre as demarcações das Capitanias de S. Paulo e Minas Gerais fundadas nas dos respectivos bispados).

Cópia. Letra do séc. XVIII. A fl. 245 a 247.

B.N.L.

F.G. 4530

(Parecer sôbre os mcios de diminuir as despesas e aumentar a receita da Capitania de S. Paulo, por ocasião da conta de 25 de fevereiro da Junta da administração e arrecadação da Real Fazenda da dita Capitania).

Cópia. Letra do séc. XVIII. A fl. 249 a 252.

B.N.L.

F.G. 4530

(Representação feita a S.M. pela Junta da Real Fazenda da Capitania de S. Paulo, sôbre os soldos que se deviam à tropa em serviço na dita Capitania e no exército do Sul e sôbre se hão-de ser pagos pelos rendimentós desta que em provisão de 17 de Novembro de 1779 se manda recolher ao Rio de Janeiro para dali irem ao Reino, ou se se há-de executar a mencionada provisão). 1780. Setembro, 11 - S. Paulo.

. Original. A fl. 253.

B.N.L.

F.G. 4530

(Representação da Junta da Real Fazenda de S. Paulo a S.M. mostrando o mau estado das rendas da capitania, e pedindo pro. vidências).

1780. Setembro, 11 - S. Paulo.

Cópia autêntica. Letra do séc. XVIII. A fl. 256 a 258. 